\title{
MACROECONOMIC ENVIRONMENT OF LATVIA'S EXPORTERS
}

\author{
Velga Ozolinga \\ Riga Technical University, Kalku str. 1, LV-1680 Riga, Latvia \\ E-mail:Velga.Ozolina@rtu.lv
}

\begin{abstract}
Analysis of macroeconomic environment is important to any enterprise. Moreover, analysis of regional or even global trends is essential to exporters. Therefore the article contains the analysis of the main macroeconomic indicators of the EU countries and Russia, as these are Latvia's main export markets. In order to evaluate development opportunities and risks, it is necessary to elaborate certain forecasts. Latvia's macroeconometric model, which is mentioned in the article, enables to calculate forecasts of the main macroeconomic indicators, allowing to evaluate the influence of the economic development of our main export partners on Latvia's economy. Despite the limitations of the use of macroeconomic models during the crisis, it is possible to use such models in scenario analysis. Several scenarios elaborated with Latvia's Macroeconometric Model, using the results of analysis, are presented in the article.
\end{abstract}

Keywords: Macroeconomic environment, economic development, export, macroeconometric model, forecasts.

\section{Introduction}

Analysis of macroeconomic environment is important to any enterprise. Evaluation of development trends of the major macroeconomic indicators allows assessment of opportunities or threats, which is significant for business planning. Moreover, analysis of regional or even global trends is essential to exporters.

Macroeconomic environment can be analysed from different perspectives using different tools. For example, enterprises may be interested only in analysis of economic situation in countries, to which they export. However, to gain a broader perspective, overall export trends of a country can be analysed, using a macroeconomic model. Macroeconomic modelling allows evaluation of the macroeconomic environment of a country in a global context, because changes in economic and political situation in partner countries can significantly influence also economic situation in a small open country (Počs, Ozolinga 2007), which is also the case of Latvia.

Therefore the aim of the article is to show, how a macro-econometric model can be used in order to evaluate the macroeconomic environment of Latvia's exporters.

In order to focus on issues of foreign demand and competitiveness, only exports of goods as well as a few major macroeconomic indicators are analysed in the article.

At the beginning of the article analysis of several macroeconomic models is presented, followed by analysis of Latvian data as well as characterisation of the Latvia's macro-econometric model. Afterwards the latest trends of the main macroeco- nomic indicators are discussed and forecasts calculated with the Latvia's macro-econometric model are presented.

\section{Analysis of factors influencing exports}

In the majority of macroeconomic models total exports is modelled using Armington model (see, for example, Celov et al. 2005) with demand and relative prices as the main factors. Also other indicators characterising competitiveness can be used instead of relative prices, for example exchange rate or real exchange rate. The real exchange rate incorporates both relative prices and exchange rate. In calculation of the real exchange rate unit labour costs, normalized unit labour costs, value added deflators, unit value of exports and consumption deflators can be used as prices (Zīle 2003). For example, in Slovenian model SLOPOL6 (Weyerstrass, Neck 2007) ratio of consumption price indexes is used in the calculation of the real exchange rate and in Finnland's model EMMA (Lehmus 2007) ratio of import prices to value added price index is used to characterise competitiveness.

The use of exchange rate both individually and within the competitiveness indicator is important, if it fluctuates. Therefore in separate time periods it raises or reduces price competitiveness of exported goods or services.

The choice of the most appropriate price index depends both on the structure of exported production and on available data. Relatively extensive information both regarding actual information and forecasts is usually available for GDP deflator and private consumption price index. If 
the majority of exported goods are consumption goods, private consumption price index is more appropriate. Otherwise GDP deflator is more suitable. Since the share of consumption goods comprises less than one third, GDP deflator is chosen in Latvia's case.

For characterisation of foreign demand, GDP or imports of partner countries is used in the majority of macroeconomic models. For example, in Spanish MCM model (Estrada et al. 2004) weighted average imports of the most important partner countries, but in Slovenian model SLOPOL6 (Weyerstrass et al. 2007) and in Estonian model (Meriküll 2004) real GDP of euro-12 countries is used.

The use of weighted average indicators may give more precise results in the sample period. However, if export structure tends to change, forecasted foreign demand will not be more accurate comparing with summary indicators. Therefore in Latvia's model the real GDP is used, which is considered to give both accurate forecasts and flexibility regarding exogenous variables.

Sometimes foreign demand is used as the only factor in export equations, for example, in Estonian model (Meriküll 2004) such a choice is justified with the fact that Estonian exporters adjust to foreign prices.

Economic theory also states that also investments in new technologies can facilitate exports and they improve competitivenss of goods. Moreover, as Latvia's domestic market is small, investors tend to orientate mainly on exporters (Libermanis 2003). Therefore the volume of exports can be connected to investments both in current and in previous periods. However in Irish MCM model (McQuinn et al. 2005) the share of manufacturing is used to characterise high export ability of foreign enterprises.

\section{Analysis of dynamics and ifluencing factors of Latvia's exports}

In the context of macroeconomic modelling, it is not useful to calculate exports by countries as it requires a lot of data and makes a model large and immense. Modelling of exports by country groups, on the other hand, provides information about the major export partners in a more concentrated way.

Latvia's export structure has faced major changes (Fig. 1). In 1995, the main export markets were the EU-15 and CIS countries (mainly Russia) with $44 \%$ and $38 \%$ respectively. After the banking crisis in Russia in 1998, export share to the CIS countries sharply decreased - to less than $9 \%$ in 2000 .

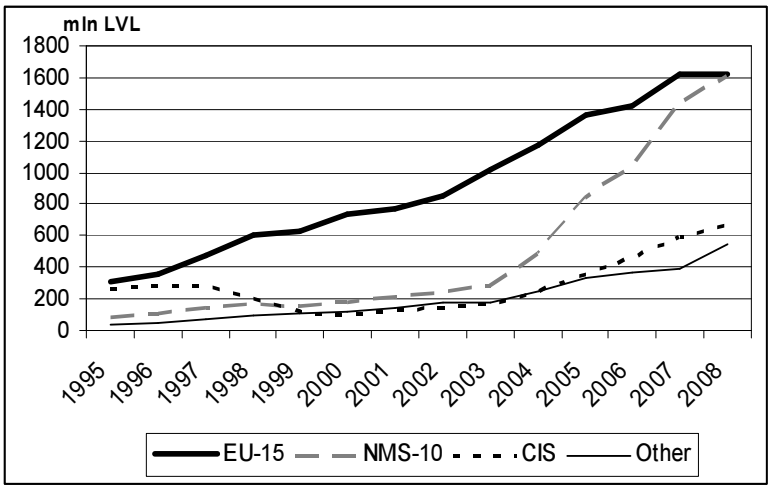

Fig. 1. Latvia's exports by country groups, mln LVL (CSB database)

Another dramatic change happened, when Latvia entered the EU in 2004. If previously the share of exports to the new member states (NMS10) grew slowly and was less than $20 \%$, then after the EU enlargement the share of exports to the NMS-10 increased from $23 \%$ in 2004 to $36 \%$ in 2008, almost reaching the value of exports to the EU-15 countries. The most important partner countries in the NMS-10 group are Estonia and Lithuania.

As changes in the group of other countries are not that dramatic and exports of other countries can not be to a large extent associated to one or two countries, for modelling of exports only three country groups were chosen-EU-15, CIS and other countries with Russia and Estonia as proxies of CIS and other countries respectively.

Direct correlation between Latvia's exports to the EU-15 countries and the real GDP of the EU15 countries exists in 1995-2005 (Fig. 2), but afterwards the trends of these two indicators are adverse. Nevertheless, the correlation coefficient for the whole sample is 0.93 .

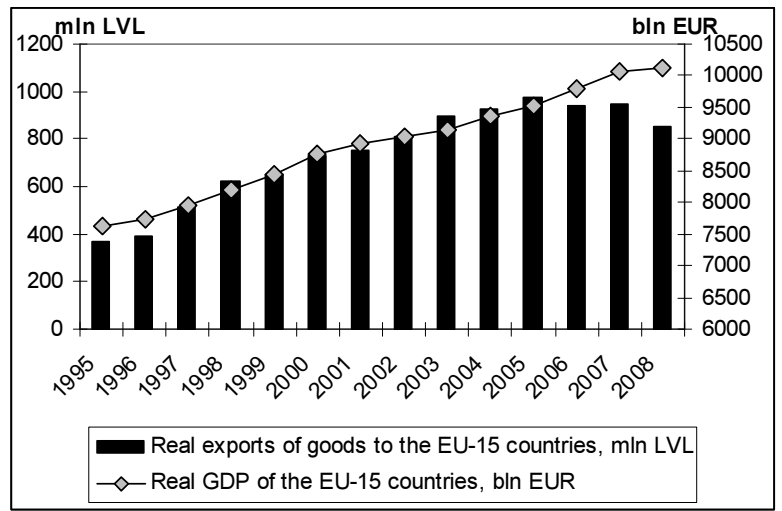

Fig. 2. Relation between Latvia's exports of goods to the EU-15 countries and real GDP of the EU-15 countries (CSB and Eurostat databases) 
Analysis of relation between Latvia's exports of goods to the EU-15 countries and the ratio of GDP deflators shows that negative value of the correlation coefficients between these indicators is only starting with 2003 (previously it was positive, which contradicts to the theoretical assumptions). It means that initially foreign demand was of a greater importance, but afterwards, together with the increase of prices, relative prices are becoming a decisive factor determining the volume of exports to the EU- 15 countries.

Relation between Latvia's exports of goods to the CIS countries and the real GDP of Russia is very close starting with 2000 (Fig. 3). Adverse trends in 1999 and 2000 are connected with the influence of Russian crisis on possibilities to sell Latvian production in the Russian market.

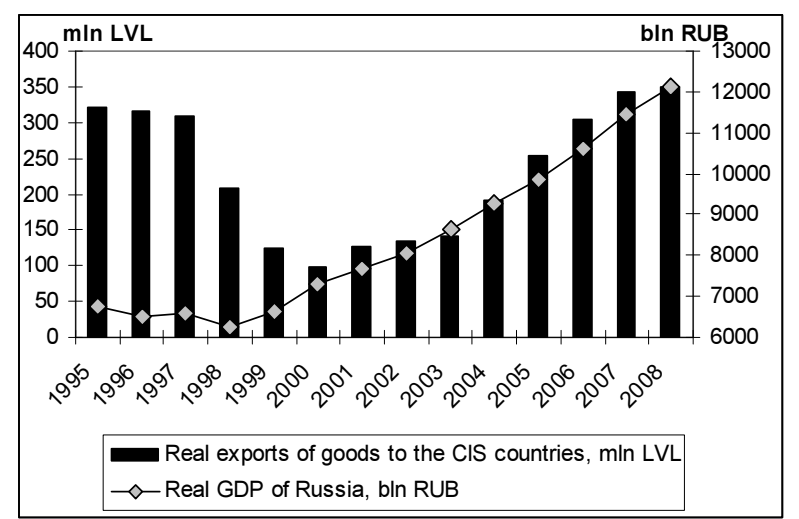

Fig. 3. Relation between Latvia's exports of goods to the CIS countries and real GDP of Russia (CSB and Russian Federal State Statistics Service databases)

During the analysis of the most appropriate indicator characterising competitiveness, average exchange rate of LVL to RUB was not selected as its influence so far has been relatively insignificant. However, together with the ratio of GDP deflators, it gives comparatively close relation with exports starting with 1998. Another alternative is to use the ratio of GDP deflators, which has strong relation to exports since 1999.

Selection of Estonia as a proxy of other countries, was done not only basing on export structure, but also on relations between foreign demand and exports. Trends of Lithuanian and Estonian GDP are similar till 2007. However, in 2008 the real GDP of Lithuania was still growing, but the real GDP of Estonia was decreasing (Fig. 4). Since exports of goods to other countries were also decreasing, the real GDP of Estonia is considered as a better choice. Therefore indicator characterising competitiveness is also connected to Estonia.

Since both Latvia and Estonia are planning to join the euro zone, fluctuations of the average ex- change rate of LVL to EEK are negligible starting with 2005. However, it can be important explaining factor before 2005. The other alternative - ratio of GDP deflators - is not a better choice, because theoretically justified (that is opposite) relation of this ratio and exports is present only till 2003.

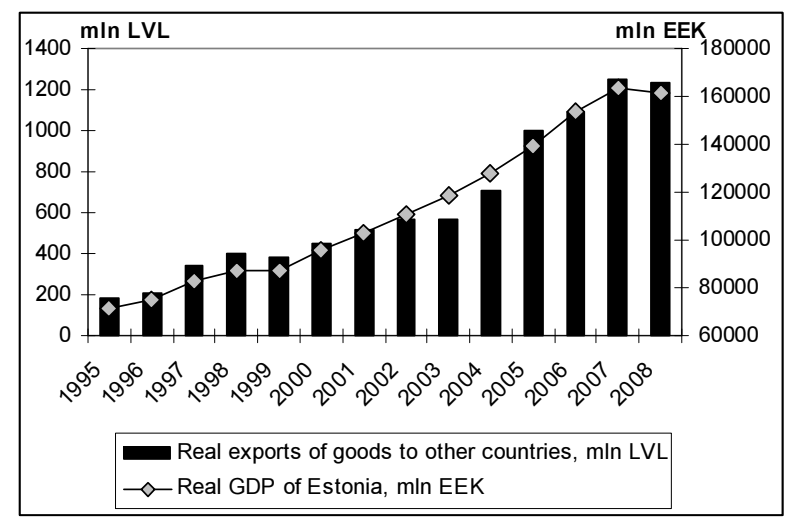

Fig. 4. Relation between Latvia's exports of goods to other countries and real GDP of Estonia (CSB and Eurostat databases)

Analysis of export data and their influencing factors shows that foreign demand is very important in determining the volume of exports, however, it is not the only one.

\section{Latvia's macro-econometric model and its export equations}

Latvia's macro-econometric model is a detailed model and it contains six sections (Fig. 5), which are related to each other. Therefore it is a suitable tool for impact analysis of macroeconomic environment in other countries on the development of Latvian economy.

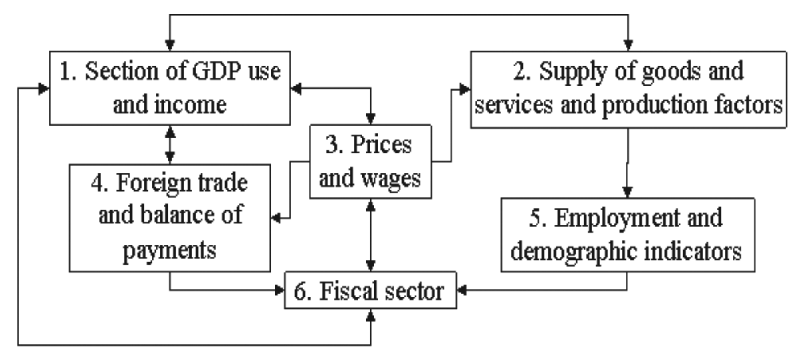

Fig. 5. The structure of Latvia's macro-econometric model

Taking into account the results of analysis of factors influencing exports, equations (1) - (3) are estimated and included in the model. Exports of goods to the EU-15, CIS and other countries are modelled in real terms, using export price index as a deflator. In the brackets below the coefficient $t$ - 
statistics is given, $R^{2}$ is the coefficient of determination, DW is Durbin-Watson statistics, P(F-stat) is the probability related to F-statistics and in square brackets the sample period is given.

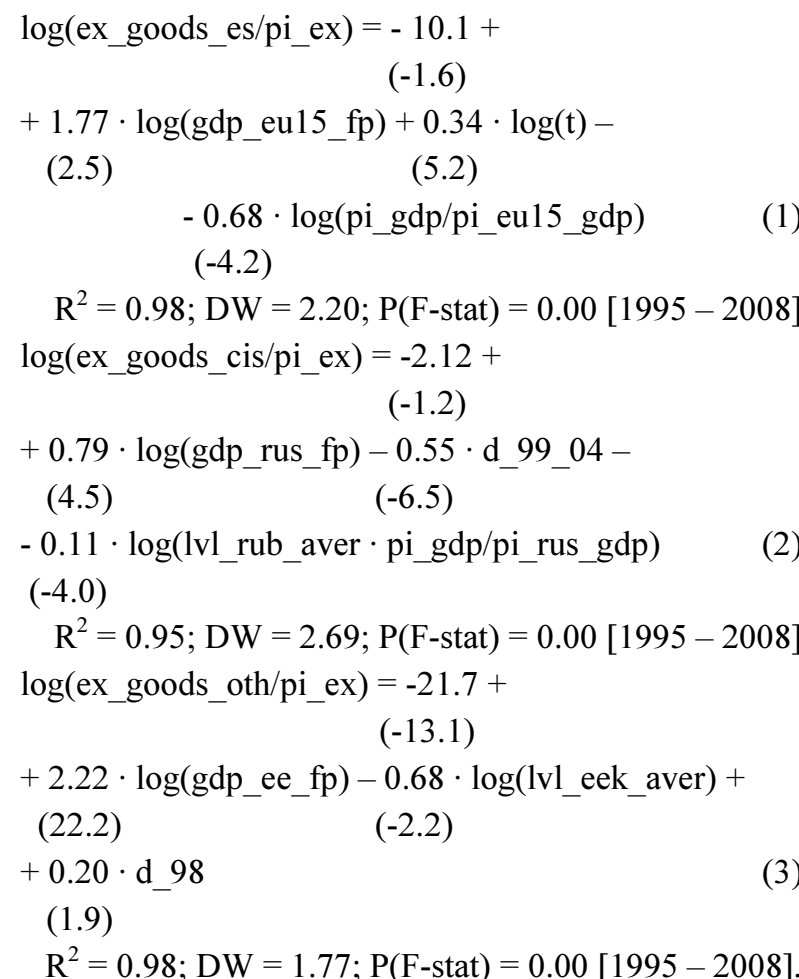
where, ex goods es - exports of goods to the EU15 countries,

ex_goods_cis - exports of goods to CIS countries, ex_goods_oth - exports of goods to other countries,

pi ex - export price index,

gdp eu15 fp - real GDP of the EU-15 countries, pi gdp - GDP deflator,

pi_eu15_gdp - GDP deflator of the EU-15 countries,

gdp_rus_fp - real GDP of Russia,

lvl_rub_aver - average exchange rate LVL to RUB,

gdp_ee_fp - real GDP of Estonia,

lvl eek aver- average exchange rate LVL to EEK,

pi_ee_gdp - GDP deflator of Estonia,

$\mathrm{t}$ - time trend $(1995=1)$,

d 9904 -dummy $(1999-2004=1$, otherwise $=0)$, d 98 - dummy $(1998=1$, otherwise $=0)$

Each of estimated equations contains a factor characterising foreign demand expressed as the real GDP, and a competitiveness indicator. The dummy variable included in equations (2) can be viewed as a policy variable. It characterises the situation from the Russian crisis in 1998, when many enterprises were forced to re-orientate to other export markets, to accession of Latvia in the EU.

\section{Analysis of macroeconomic environment in Latvia and abroad}

The latest trends of macroeconomic indicators show some negative and some positive tendencies. For example, rapid economic growth of Latvia, which in 2007 was approximately $10 \%$ (Fig. 6 ), is replaced by a dramatic downturn with a decline of $18-19 \%$ in the first three quarters of 2009. And it seems that the situation will not be much better in the fourth quarter. Analysis of GDP use indicates that only exports show some improvements in the third quarter of 2009, but still the growth rate is negative $(-15 \%)$. It means that demand is very restricted and many enterprises struggle to sell their production and have problems with current assets.

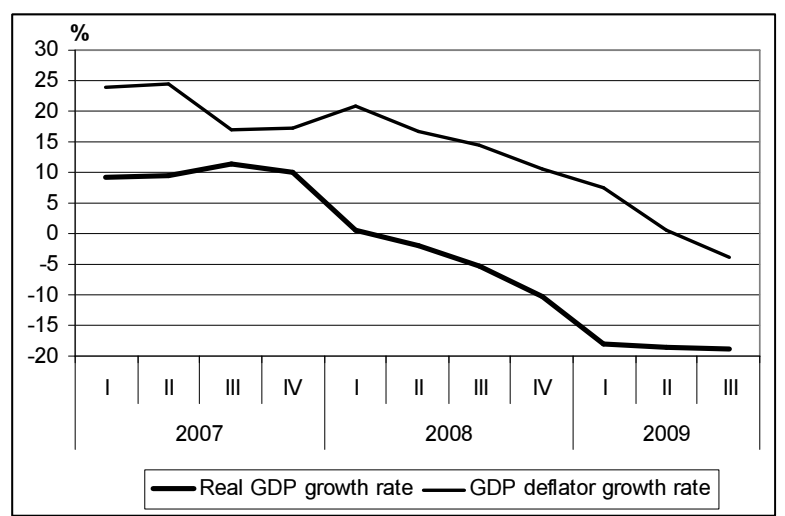

Fig. 6. Dynamics of Latvian indicators, \% (CSB database)

On the other hand, prices do not increase as much as before and in the third quarter of 2009 they are even decreasing. Similar situation can be witnessed also regarding wages, which means that at least some part of production costs decreases. It gives enterprises a chance to improve their competitiveness.

Situation in Latvia's export market is in a way similar, however economic slowdown has happened a bit later than in Latvia and in the third quarter of 2009 some improvements can be witnessed. For example, recession in the EU-15 countries in total began only in the fourth quarter of 2008 , but the prices are decreasing already since the second quarter of 2008 (Fig. 7).

Real GDP of Russia is decreasing only in 2009 (Fig. 8). However, GDP deflator growth rates have changed from more than $20 \%$ to negative more rapidly than in Latvian case.

In Estonian case decrease of GDP began in the fourth quarter of 2008 , but prices started to lower in the second quarter of 2009. 


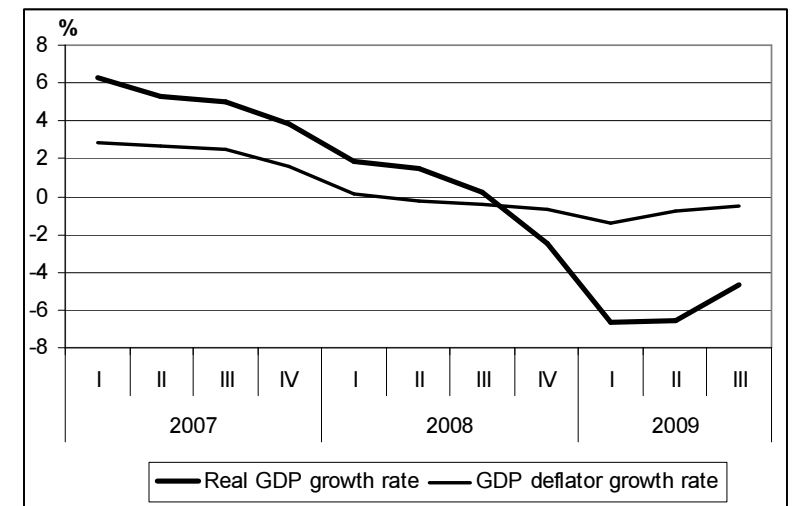

Fig. 7. Dynamics of the EU-15 indicators, \% (Eurostat database)

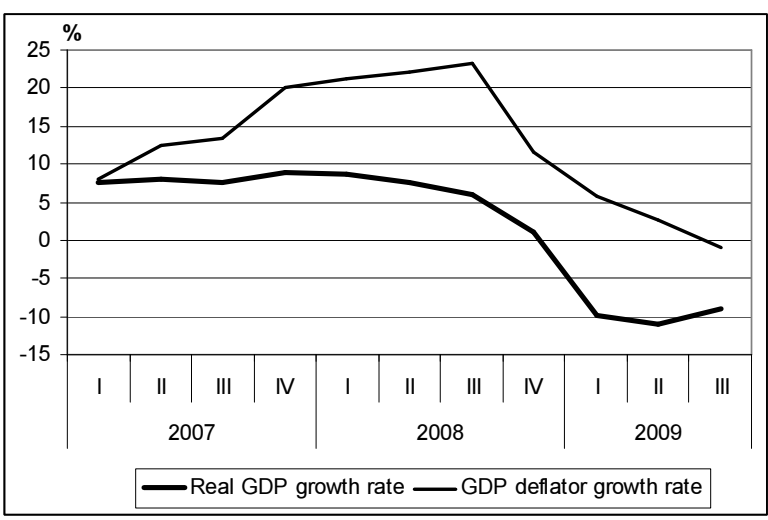

Fig. 8. Dynamics of Russian indicators, \% (Russian Federal State Statistics Service database)

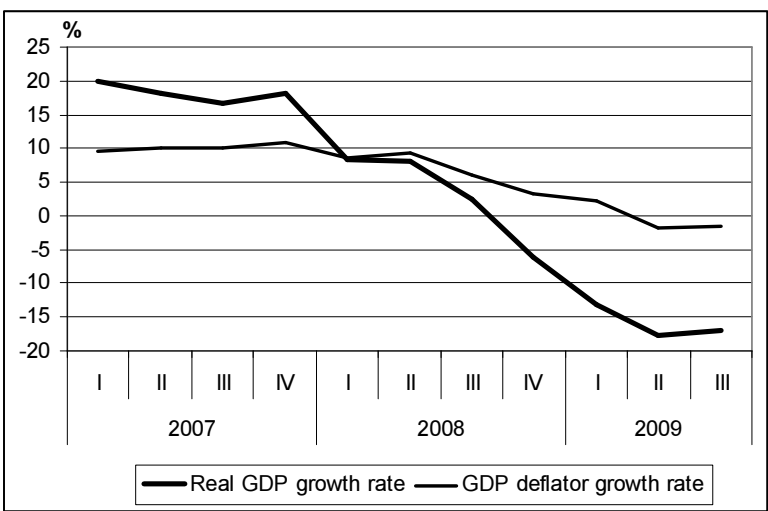

Fig. 9. Dynamics of Estonian indicators, \% (Eurostat database)

It means that situation in export markets is likely to stabilize and improve earlier than in Latvia, which gives exporters more opportunities comparing with domestic producers. However, lowering of prices in other countries reduce possibilities of exporters to sell more production because of increased competitiveness.

\section{Forecasts}

In order to calculate forecasts with the help of the model, it is necessary to determine possible values of the exogenous indicators. In case of indicators characterising foreign economies, prognoses of Eurostat, International Monetary Fund (World ... 2009) and Institute of Economic Forecasting of the Russian Academy of sciences (Прогноз ... 2008) together with the author's assumptions are used. Growth rates of GDP and GDP deflators used in the base scenario of the model are presented in Table 1.

Table 1. Forecasts of growth rates of foreign GDP and GDP deflators, \%

\begin{tabular}{|c|c|c|c|c|c|c|}
\hline & \multicolumn{3}{|c|}{ Real GDP } & \multicolumn{3}{c|}{ GDP deflator } \\
\hline Year & EU15 & Russia & Estonia & $\begin{array}{c}\text { EU1 } \\
5\end{array}$ & Russia & Estonia \\
\hline 2009 & -4.0 & -6.0 & -10.0 & 1.3 & 3.5 & 0.5 \\
\hline 2010 & -0.1 & 0.5 & -1.0 & 1.2 & 14.3 & 0.0 \\
\hline 2011 & 1.5 & 3.3 & 2.3 & 2.0 & 12.9 & 0.5 \\
\hline 2012 & 2.0 & 3.4 & 4.0 & 2.0 & 11.9 & 1.5 \\
\hline 2013 & 2.5 & 4.7 & 4.5 & 2.0 & 8.0 & 2.5 \\
\hline 2014 & 3.0 & 5.1 & 4.5 & 2.0 & 8.0 & 2.5 \\
\hline 2015 & 3.0 & 5.1 & 4.5 & 2.0 & 8.0 & 2.5 \\
\hline
\end{tabular}

The second scenario implies lower foreign demand - longer and deeper recession and slower recovery.

According to the calculations of the model, together with even greater reduction of domestic and foreign demand, comparing with 2008, also the real GDP of Latvia will continue to decrease at least next two or three years (Fig. 10). Also recovery of Latvia's economy is not forecasted to be fast - real GDP in 2015 might be only a bit higher than in 2008 or even lower than in 2007.

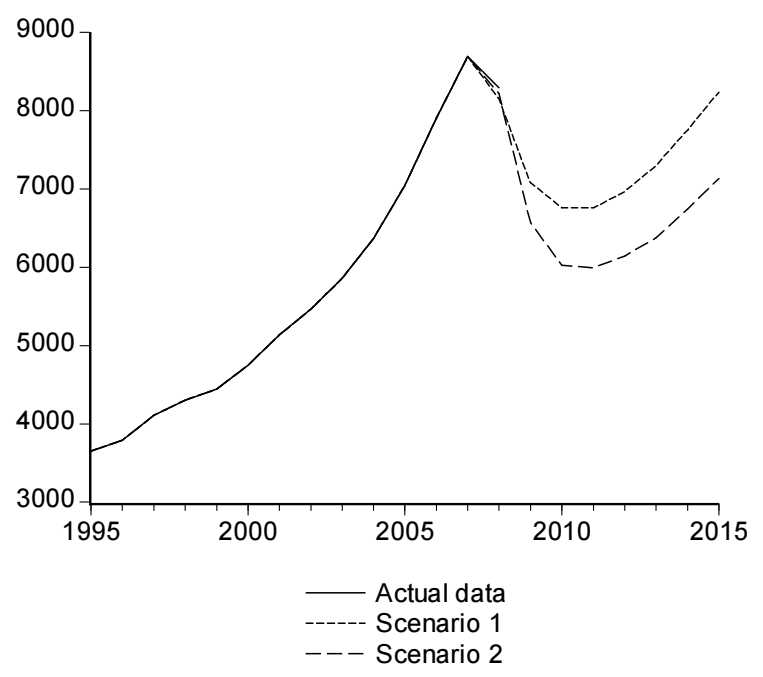

Fig. 10. Forecasts of the real GDP of Latvia, mln LVL

Similarly wages, due to the economic slowdown and high unemployment rates, will decrease 
during the next few years and further their development will more or less correspond to the previous trend.

As recovery in other countries is forecasted to start earlier, also prognoses of exports are optimistic. According to the forecasts, economic recession only in 2009 reduces exports of goods to the EU15 countries (Fig. 11).

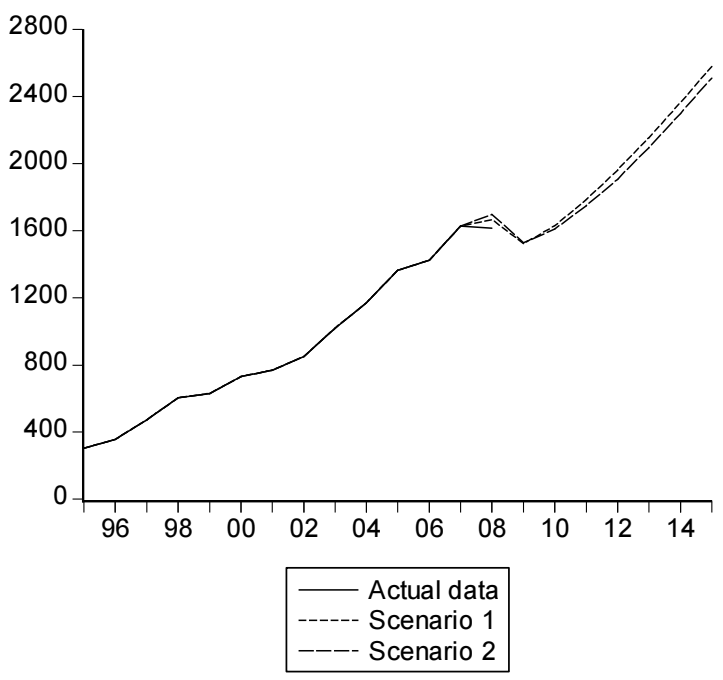

Fig. 11. Forecasts of exports of goods to the EU-15 countries, mln LVL

Similar situation is modelled regarding exports of goods to the CIS countries (Fig. 12). However, in this case exports are later increasing slower than in the case of the EU-15 countries.

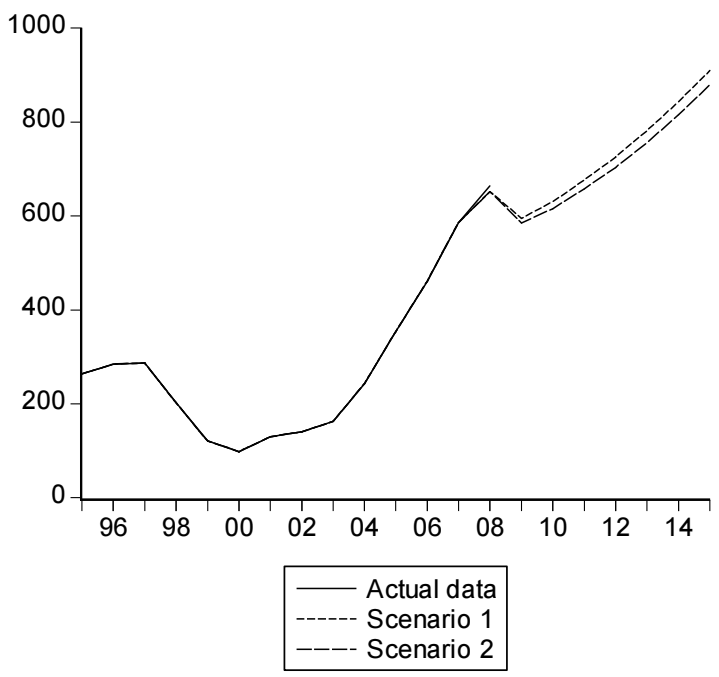

Fig. 12. Forecasts of exports of goods to the CIS countries, mln LVL

However, due to the fact that the Baltic States face deeper recession than many other countries, also exports to other countries is forecasted to decrease more in 2009 (Fig. 13).

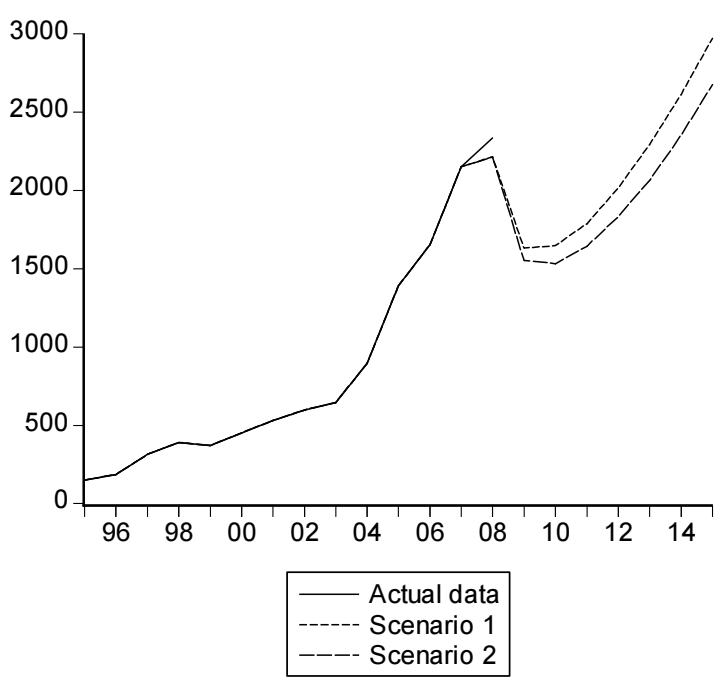

Fig. 13. Forecasts of exports of goods to other countries, mln LVL

As domestic demand is forecasted to recover later and slower, also imports will decrease during the next few years. Therefore net exports of goods and services will become positive in 2010 or 2011 (Fig. 14).

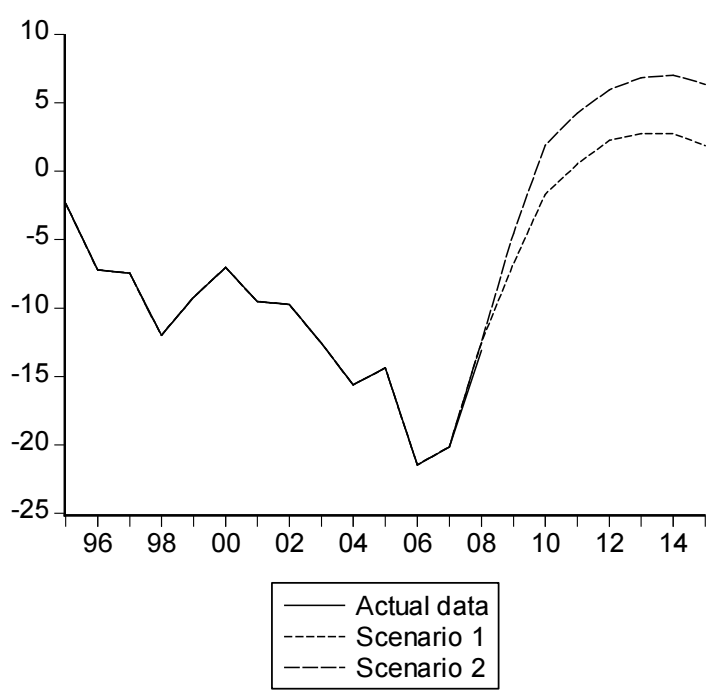

Fig. 14. Forecasts of the ratio of foreign trade balance to GDP, \%

In such a way net exports will help to improve the balance of payments, which, according to the database of the Bank of Latvia, is already positive in 2009. Therefore also economic development of Latvia will become less balanced. 


\section{Conclusions}

The use of a macroeconomic model in analysis of macroeconomic environment of exporters allows investigating a wide range of scenarios. The main way of analysis implies evaluation of influence of changes in foreign demand and other macroeconomic indicators on the volumes of exports.

Although in majority of macroeconomic models exports is considered as a single variable, the Latvia's macro-econometric model includes calculation of exports of goods by groups of countries. It allows designation of macroeconomic indicators of particular countries or groups of countries to foreign demand and competitiveness indicators, which are the main factors influencing exports. Also data analysis shows that foreign demand is not the only factor influencing Latvia's exports.

Since Latvia's macro-econometric model is a detailed model and it contains also disaggregated exports equations, it is a suitable tool for impact analysis of macroeconomic environment in other countries on the development of Latvian economy.

Currently Latvian economy is facing crisis with low both domestic and foreign demand. However, situation abroad seems to improve, which is evident also in forecasts calculated with the model.

\section{References}

Celov, D.; Vilkas, E.; Grinderslev, D.; Andersen, F. M. Macro-econometric model for Lithuania, Economic Modelling 22(4), July: 707-719.

CSB Database. 2009. [cited 1 January 2010]. Available from Internet: <http://data.csb.gov.lv>.

Database of the Bank of Latvia. 2009. [Cited 1 January 2010]. Available from Internet: $<$ http://www.bank.lv>.

Estrada, A.; Fernandez, J. L.; Moral, E.; Regil, A. V. 2004. A Quarterly macroeconometric model of the
Spanish economy. Banco de Espana Documentos de Trabajo 0413 [Working Papers of the Bank of Ispania].

Eurostat Database 2009. [Cited 1 January 2010]. Available from Internet:

$<$ http://epp.eurostat.ec.europa.eu/portal/page/portal/ eurostat/home/>.

Lehmus, M. 2007. Empirical Macroeconomic Model of the Finnish Economy (EMMA). Discussion Papers of Labour Institute for Economic Research. Helsinki: Labour Institute for Economic.

Lībermanis, G. 2003. Starptautiskie ekonomiskie sakari un Latvija [International economic relations and Latvia]. Riga: Kamene.

McQuinn, K.; O’Donnell, N.; Ryan, M. 2005. Macroeconometric model for Ireland. Research Technical Paper of Central Bank and Financial Services Authority of Ireland, December, 146-172.

Meriküll, J. 2004. Macroeconometric modelling of the Estonian economy. Modelling the economies of the Baltic Sea region. Tartu: Tartu University Press.

Počs, R.; Ozoliṇa, V. 2007. Makroekonomisko procesu modelēšana [Macroeconomic modeling]. Riga: RTU Izdevniecība, Latvia.

Russian Federal State Statistics Service database 2009. [Cited 1 January 2010]. Available from Internet: $<\mathrm{http}$ ://www.gks.ru>.

Zīle, H. 2003. Latvijas ārējie ekonomiskie sakari [Latvian external economic relations]. Riga, Turiba: Biznesa augstskola press.

Weyerstrass, K.; Neck, R. 2007. SLOPOL6: Macroeconomic model for Slovenia, International Business \& Economics Research Journal 6(11): 81-94.

World Economic Outlook Database of International Monetary Fund April 2009. [Cited 17 October 2009]. Availabe from Internet: $<$ http://www.imf.org $>$.

Прогноз индикаторов экономики РФ: 2008-2012 гг. (базовый сценарий). 2009. [Prognoz indikatorov ekonomiki RF: 2008-2012 gg. (bazovyj scenarij)] [online] [Cited 15 October 2009]. Available from Internet: $<$ http://www.macroforecast.ru>. 